\title{
Dissolution of Limestone and Sustainable Groundwater Development from Underground Dam Area
}

\begin{abstract}
A.K.M. Adham ${ }^{1}$, Akira Kobayashi ${ }^{2}$ and Shun Teranishi ${ }^{3}$
Abstract: The effect of climatic change of underground dam areas on the dissolution of limestone was observed by using numerical simulation. The examination is related to the sustainable groundwater development from the underground dam constructed in the south islands in Japan. The model includes dispersion/diffusion, advection, ion exchange, formation of complexes in the aqueous phase, and the dissociation of water. The mass action, transport, and the site action equations are expressed in a differential/algebraic form and solved by FEM. As the acidification of the rain water progresses, the dissolution of limestone increases. As a result, calcium ion concentrations increased and finally will block the screen of pumping well and also deteriorated the quality of groundwater. Increase of intensity of rain, which coincides with the increase of velocity of water, caused the increase in the dissolution of limestone. Dissolution of limestone was not favored with increasing temperature. It was found that the areas upstream and relatively distant from the dam body are safer than areas near the body, as regard extraction of groundwater of this underground dam area.
\end{abstract}

Keywords: Dissolution; Limestone; pH; Rainfall; Temperature; Climatic change; Chemical reaction; Underground dam; Sustainable groundwater

\section{Introduction}

In Japan, a lot of underground dams have been constructed so far and these are located in islands and isolated peninsular regions (Fujino et al., 2005). In an underground dam, the cut-off wall (dam body) is constructed in the aquifer and underground water is stored. Such dams are very effective as water sources in arid zones and isolated areas and their installations improve the water supply situation quite rapidly. However, the quality of the natural water supplied by underground dams depends critically on the chemical reactions undergoing in their environment, in particular, the chemical dissolution of bed rock/minerals (limestone). Rocks coming in contact with water constitute the major sources of dissolved species to natural water. They start the water-rock reaction and this reaction moves forward towards equilibrium by dissolving or leaching bedrock minerals in water. Solute concentration in the water is proportional to the reactivity of bedrock minerals forming the catchment (Yadav and Chakrapani, 2006). Natural waters from carbonate aquifers have been identified as under-saturated with respect to calcite. This under-saturation suggests that dissolution kinetics of calcite in natural environments may be relatively slow and may play an important role in the chemical evolution of groundwater systems in carbonate rocks (Langmuir, 1971).

The rate of dissolution of any mineral is dependent upon the rate of transport of reactants and products between the mineral surface and the bulk solution. Depending upon the

${ }^{1} \mathrm{Ph} . \mathrm{D}$. Student, Graduate School of Agriculture, Kyoto University, Kitashirakawa-oiwake-cho, Sakyo-ku, Kyoto 606- 8502, Japan (Corresponding Author) E-mail: adham@kais.kyoto-u.ac.jp

Associate Professor, Graduate School of Agriculture, Kyoto University, Kitashirakawa-oiwake-cho, Sakyo-ku, Kyoto 606- 8502, Japan

${ }^{3}$ MS Student, Graduate School of Agriculture, Kyoto University, Kitashirakawa-oiwake-cho, Sakyo-ku, Kyoto 606- 8502, Japan hydrodynamic and chemical characteristics of the environment, one or all of these processes may be important in determining dissolution rate (Plummer and Wigley, 1975). Dissolution rates of limestone in carbonated aqueous solutions are determined by three processes: (1) kinetics of dissolution at mineral surface, which depends on the chemical composition of the solution at the liquid-rock boundary; (2) mass transport by diffusion away from this boundary for the dissolved material $\mathrm{Ca}^{2+}, \mathrm{HCO}_{3}{ }^{-}$, and $\mathrm{CO}_{3}{ }^{2-}$ and towards this boundary for the reactant $\mathrm{CO}_{2}$; and (3) conversion of $\mathrm{CO}_{2}$ into $\mathrm{H}^{+}$and $\mathrm{HCO}_{3}{ }^{-}$(Kaufmann and Dreybrodt, 2007).

Several experimental studies of limestone dissolution have been carried out. Sjoberg and Richard (1984) studied temperature dependence of calcite dissolution kinetics in aqueous solutions with $\mathrm{pH} 2.4-8.4$, from $1^{\circ} \mathrm{C}$ to $62^{\circ} \mathrm{C}$. Noiriel et al. (2005) conducted an experiment on hydraulic properties and microgeometry evolution accompanying limestone dissolution by acidic water. Liang et al. (1996) investigated the dissolution kinetics at the calcite-water interface. Nierode and Williams (1971), and Berner and Morse (1974) have shown that transport processes play an important role in the rate of dissolution of calcite in stirred solutions with $\mathrm{pH}$ less than 4. Above $\mathrm{pH} 4$, dissolution in stirred solutions is considerably slower than that predicted by simple transport process models and is thought to be primarily determined by the kinetics of surface reaction(s).

Reaction kinetics and hence the concentrations of solutes depend on a set of external parameters such as $\mathrm{pH}$, temperature and rainfall and a set of internal physical parameters of the dam body such as permeability, effective porosity, and thickness of the aquifer. The quality of water obtained from the dam reservoirs depends, in the final analysis, on the interplay of these parameters. Any predictive model of the distribution of solutes in the reservoir water must take 
these into account and should be based on the basic processes mentioned above.

These studies have acquired added significance in the background of greenhouse gas, especially carbon dioxide emission by human activity. This has led to global warming, which has not only raised the ambient temperature but has also lowered the $\mathrm{pH}$ of water-bodies and changed precipitation intensities all over the world (Solomon et al, 2009). All of these factors affect reactions favoring dissolution of carbonaceous stones (Thornbush and Viles, 2007). So determining those effects are very important for the sustainable groundwater development from underground dam areas constructed in limestone, which is the main geology of islands having underground dams in Japan. These reactions also play a major role in increasing pollution of the ground surface specially groundwater contamination and problems of pumping well equipments. The objective of our research is to identify the climatic change affects of $\mathrm{pH}$, rainfall and temperature, which are the main factors causing dissolution of limestone, on the operation of the underground dam. In this communication we present the results of numerical simulation studies of spatiotemporal distribution of $\mathrm{Ca}^{2+}$ ion concentration in the vicinity of an underground dam.

\section{Theoretical Background}

\subsection{Seepage Analysis}

The permeability of all elements is estimated by Kriging (Teranish et al., 2009). Based on the data, the groundwater flow analysis is carried out. Since the depth of the aquifer is smaller than the horizontal distance of the region, the quasi-three dimensional model was used for the analysis. The basic equation is written as Eq. (1).

$$
D \lambda \frac{\partial h}{\partial t}=k D\left(\frac{\partial^{2} h}{\partial x^{2}}+\frac{\partial^{2} h}{\partial y^{2}}\right)+\varepsilon
$$

where, $\lambda$ is the effective porosity, $k$ is the permeability, $D$ is the thickness of aquifer, $h$ is the total head and $\varepsilon$ is the groundwater recharge. Eq. (1) is solved by using the finite element method on the interval of 10 days.

\subsection{Dissolution Chemistry}

In $\mathrm{CO}_{2}-\mathrm{H}_{2} \mathrm{O}$ system, dissolved inorganic carbon exists in one of four major forms: $\mathrm{CO}_{2 \mathrm{aq}}, \mathrm{H}_{2} \mathrm{CO}_{3}, \mathrm{HCO}_{3}{ }^{-}$and $\mathrm{CO}_{3}{ }^{2-}$. The main chemical reactions involving these species are (1) the conversion of carbon dioxide into hydrogen and bicarbonate, (2) the dissociation of bicarbonate into hydrogen and carbonate ions and (3) the dissolution of limestone. Since almost all of these reactions depend on the ambient $\mathrm{pH}$ and temperature, distribution or relative concentration of these species is also a function of $\mathrm{pH}$ and temperature.

Dissolution of $\mathrm{CO}_{2 \text { aq }}$ takes place according to the following reactions:

$$
\mathrm{CO}_{2}+\mathrm{H}_{2} \mathrm{O}_{\rightarrow}^{\leftarrow} \mathrm{H}_{2} \mathrm{CO}_{3 \rightarrow}^{\leftarrow} \mathrm{H}^{+}+\mathrm{HCO}_{3}^{-}
$$

The equilibrium constants for Eq. (2) are:

$$
\left(\mathrm{H}_{2} \mathrm{CO}_{3}\right)=10^{-\log K_{\mathrm{CO}_{2}}} \times P_{\mathrm{CO}_{2}}
$$

where, $\left(\mathrm{H}_{2} \mathrm{CO}_{3}\right)=$ concentration of $\mathrm{H}_{2} \mathrm{CO}_{3}, \mathrm{~K}_{\mathrm{CO} 2}=$ Equilibrium constant for $\mathrm{CO}_{2}$ dissolution and $\mathrm{P}_{\mathrm{CO} 2}=$ Pressure of $\mathrm{CO}_{2}$

and

$$
\frac{\left(\mathrm{HCO}_{3}^{-}\right)\left(\mathrm{H}^{+}\right)}{\left(\mathrm{H}_{2} \mathrm{CO}_{3}\right)}=\frac{\left(\mathrm{HCO}_{3}^{-}\right)\left(\mathrm{H}^{+}\right)}{10^{-\log K_{\mathrm{CO}_{2}}} \times P_{\mathrm{CO}_{2}}}=10^{-\log K_{\mathrm{H}_{2} \mathrm{CO}_{3}}}
$$

Hydrogen carbonate or bicarbonate ion dissociates as

$$
\mathrm{HCO}_{3}^{-} \underset{\rightarrow}{\leftarrow} \mathrm{H}^{+}+\mathrm{CO}_{3}^{2-}
$$

The equilibrium constant for Eq. (3) is:

$$
\begin{gathered}
\left(\mathrm{HCO}_{3}^{-}\right)=\frac{10^{-\log \mathrm{H}_{2} \mathrm{CO}_{3}-\log \mathrm{CO}_{2}} \times P_{\mathrm{CO}_{2}}}{\left(\mathrm{H}^{+}\right)} \\
-\log \left(\mathrm{HCO}_{3}^{-}\right)=-\left(\log K_{\mathrm{H}_{2} \mathrm{CO}_{3}}+\log K_{\mathrm{CO}_{2}}\right)-\log P_{\mathrm{CO}_{2}}-\mathrm{pH} \\
-\log \left(\mathrm{CO}_{3}^{2-}\right)=-\left(\log K_{\mathrm{CO}_{2}}+\log K_{\mathrm{H}_{2} \mathrm{CO}_{3}}+\log K_{\mathrm{HCO}_{3}^{-}}\right) \\
-\log P_{\mathrm{CO}_{2}}-2 \mathrm{pH} \\
\mathrm{pH}=\frac{r}{r_{\max }}\left(\mathrm{pH}_{\mathrm{r}}-\mathrm{pH}_{0}\right)+\mathrm{pH}_{0}
\end{gathered}
$$

where, $\mathrm{pH}_{\mathrm{r}}$ is the $\mathrm{pH}$ in rain and $\mathrm{pH}_{0}$ is assumed to be 8 , $r_{\max }$ is the maximum rain data in the duration, $r$ is the rain data at each time step. $\mathrm{pH}$ in groundwater is assumed to 8 . We assume $\mathrm{pH}$ in rain water is small but when rain water seeps into the ground, it changes the groundwater $\mathrm{pH}$ and this has a considerable effect on dissolution of $\mathrm{CaCO}_{3}$. After this dissolution, groundwater $\mathrm{pH}$ quickly returns to 8 . The chemical composition of the bedrock tends to stabilize (buffer) the $\mathrm{pH}$ of the groundwater. The longer the contact time, the larger is the effect of the rock chemistry on the composition and $\mathrm{pH}$ of the groundwater. Actually groundwater $\mathrm{pH}$ is usually from 7 to 8 . So we assume groundwater $\mathrm{pH}$ is 8 . The treatment of $\mathrm{pH}$ in the groundwater is introduced to reduce the large effects of $\mathrm{pH}$ in the chemical reactions.

Dissolution of calcium carbonate (limestone) is expressed by the equation which is,

$$
\mathrm{CaCO}_{3} \underset{\rightarrow}{\leftarrow} \mathrm{Ca}^{2+}+\mathrm{CO}_{3}^{2-}
$$

The equilibrium constant for Eq. (5) is:

$$
\begin{gathered}
\left(\mathrm{Ca}^{2+}\right)=\frac{10^{-\log K_{\mathrm{CaCO}_{3}}}}{\left(\mathrm{CO}_{3}^{2-}\right)} \\
\left(\mathrm{Ca}^{2+}\right)\left(\mathrm{CO}_{3}^{2-}\right)=10^{-\log K_{\mathrm{CaCO}_{3}}}
\end{gathered}
$$

The equilibrium constants are calculated by those equations dependent on temperature which have been suggested by Plummer and Busenberg (1982) as: 


$$
\begin{aligned}
\log K_{\mathrm{CO}_{2}=} & 108.3865+0.01985076 T-6919.53 / T \\
& -40.45154 \log T+669365 / T^{2} \\
\log K_{\mathrm{H}_{2} \mathrm{CO}_{3}}= & -356.3094-0.06091964 T+21834.37 / T \\
& +126.8339 \log T-1684915 / T^{2} \\
\log K_{\mathrm{HCO}_{3}}= & -107.8871-0.03252849 T+5151.79 / T \\
& +38.9256 \log T-563713.9 / T^{2} \\
\log K_{\mathrm{CaCO}_{3}}= & -171.9065-0.077993 T+2839.319 / T \\
& +71.595 \log T
\end{aligned}
$$

where $T$ is absolute temperature ( $\mathrm{K})$, which is assumed to be the same as actual temperature.

\subsection{Transport Analysis}

The governing equation is used to describe concentration distributions in the rocks. The transport equations include the effects of advection and hydrodynamic dispersion.

$$
\frac{\partial C}{\partial t}=\left(C v_{i}\right)_{, i}+\left(D_{i j} C_{, j}\right)_{, i}+R=0
$$

where, $C$ is the concentration of the components (solutes) which are $\mathrm{Ca}^{2+}$ and $\mathrm{CO}_{3}{ }^{2-}, v_{\mathrm{i}}$ is the Darcy velocity vector; $D_{i j}$ is the hydrodynamic dispersion coefficient tensor, $R$ is the rate of dissolution of components. For solving the transport Eq. (6), firstly we need the $\mathrm{R}$ value of $\mathrm{CO}_{3}^{2-}$, in this case we have got this value from Eqs. (3) and (4) for every time steps, where Eq. (3) is a function of both $\mathrm{pH}$ and temperature. Then we have got the distribution of $\mathrm{CO}_{3}{ }^{2-}$ by solving transport equation. Again, for calculating of $\mathrm{Ca}^{2+}$, we used the solved $\mathrm{CO}_{3}{ }^{2-}$ values and put in the Eq. (5) and we have got the $\mathrm{R}$ value of $\mathrm{Ca}^{2+}$ and then by using Eq. (6) finally we got the distribution of $\mathrm{Ca}^{2+}$. Summation convention is applied in Eq. (6). $D_{i j}$ is the following relations with velocity:

$$
\begin{gathered}
D_{x x}=\frac{\varepsilon_{L} v_{x}^{2}}{|v|}+\frac{\varepsilon_{T} v_{y}^{2}}{|v|}+D_{0} \\
D_{y y}=\frac{\varepsilon_{L} v_{y}^{2}}{|v|}+\frac{\varepsilon_{T} v_{x}^{2}}{|v|}+D_{0} \\
D_{x y}=D_{y x}=\left(\varepsilon_{L}-\varepsilon_{T}\right) \frac{v_{x} v_{y}}{|v|}
\end{gathered}
$$

where $\varepsilon_{L}$ and $\varepsilon_{T}$ are longitudinal and transverse dispersivity. In this analysis, $\varepsilon_{L}=1.0 \mathrm{~m}$ and $\varepsilon_{T}=0.1 \mathrm{~m}$ is assumed. Because dispersivities are from $10^{-2}$ to $1 \mathrm{~cm}$ for laboratory experiments and range from $10^{-1}$ to $10^{2} \mathrm{~m}$ for tracer test in the more heterogeneous porous materials typically encountered in the field (Klotz et al., 1980). $D_{0}$ is ignored in respect of high velocity.

Eq. (6) is multiplied by the thickness of strata and solved by upstream FEM.

3 Numerical Conditions of Chemical Transport

We have based our calculations on the actual rainfall and temperature data around the subsurface dam at Miyakojima Island in Japan. The rainfall and temperature data was taken for every 10-days average from March, 1994 to May, 1995. The analysis region of this study is shown in Figure 1, while Figure 2 shows the actual rainfall and temperature data, averaged for every 10-day over the site, over a period of 450 days. The analysis region is east to west about $2 \mathrm{~km}$ and south to north about $3 \mathrm{~km}$. Analysis region was divided to 1680 elements as well as 1764 nodes. Three points are chosen as sample points which are the representative points of actual pumping area for analysis: while $\mathrm{A}$ and $\mathrm{C}$ are points near the dam body and are chosen for variations over a short length scale, B is chosen away from the dam body and upstream, to see the effect of concentration on pumping. Same study region and finite element mesh is used for seepage and transport analysis.

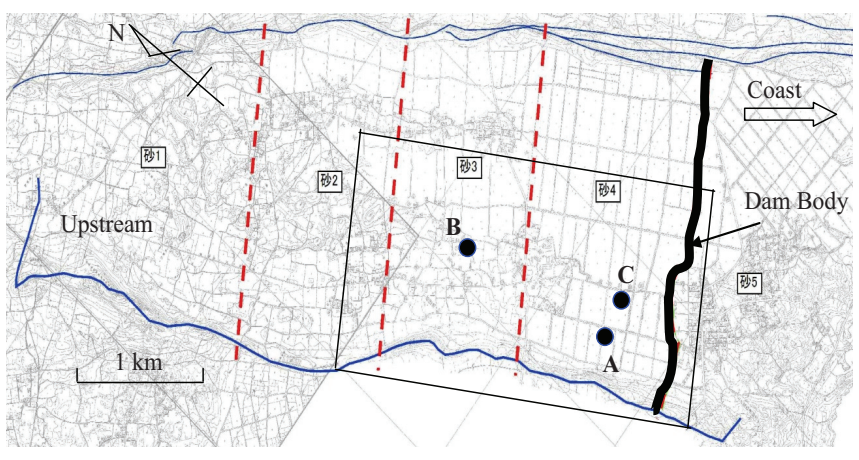

Figure 1: Analysis region of this study

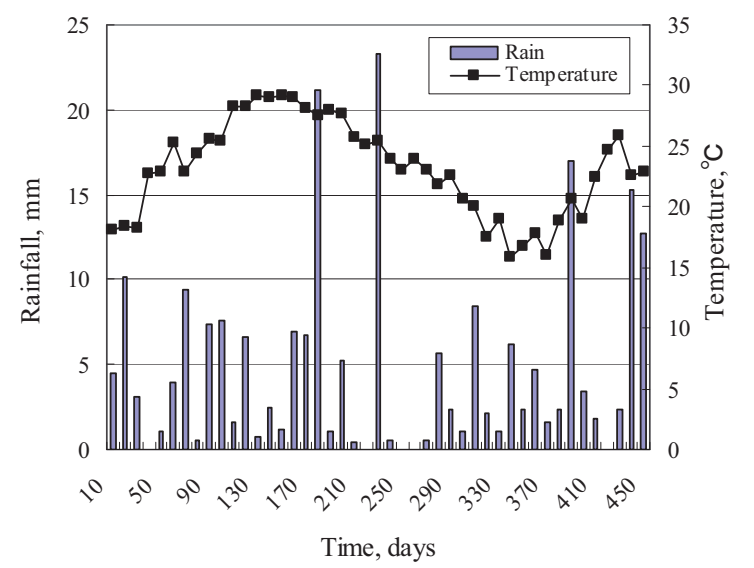

Figure 2: 10-days averaged rainfall and temperature

\subsection{Results of Seepage Analysis}

We have used a result of seepage analysis which has been obtained by Teranishi et al. (2009). Figure 3 shows the permeability distribution obtained by Kriging. The Kriging method has also been used to find the distribution of porosity and thickness. Figure 3 is a typical example of this permeability distribution. Calculating procedure of distributions of other parameters was similar to the permeability distribution. The recharge source was only a rainfall because there are few rivers in Miyakojima. The rainfall data 
was for 450 days from March, 1994. The daily amount of recharge was calculated from the daily rainfall and the daily evaporation by using the tank model. The downstream boundary was prescribed by the groundwater level at sea level. The other boundaries of the analysis region were assumed to be no flux condition. The groundwater analysis was carried out by the estimated model and the model was validated with the actual data of groundwater level. Figure 4 shows the groundwater level both for model and actual measurement and rainfall with time at the observation point near point $A$ in Figure 1. It is shown that water level of the model is going up with the time and trend is similar to the measured water level, though the water level is going much when there are lots of rainfalls. So it can be concluded that tendency of increasing groundwater level is similar to the measurement, while excessive response of groundwater level is calculated. Probably this is caused from the estimation of groundwater recharge by Tank Model, which may not be properly calculated. Distribution of velocity vector is not influenced since the excessive response of groundwater can be seen for all regions. Change in thickness of aquifer is obtained from the calculated results.

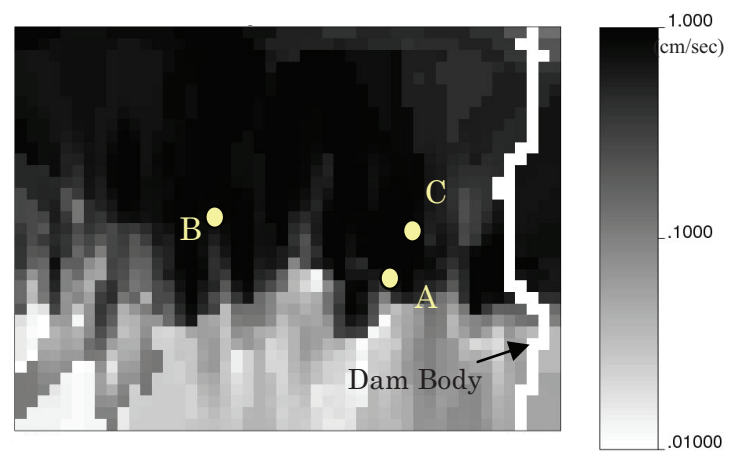

Figure 3: Distribution of permeability

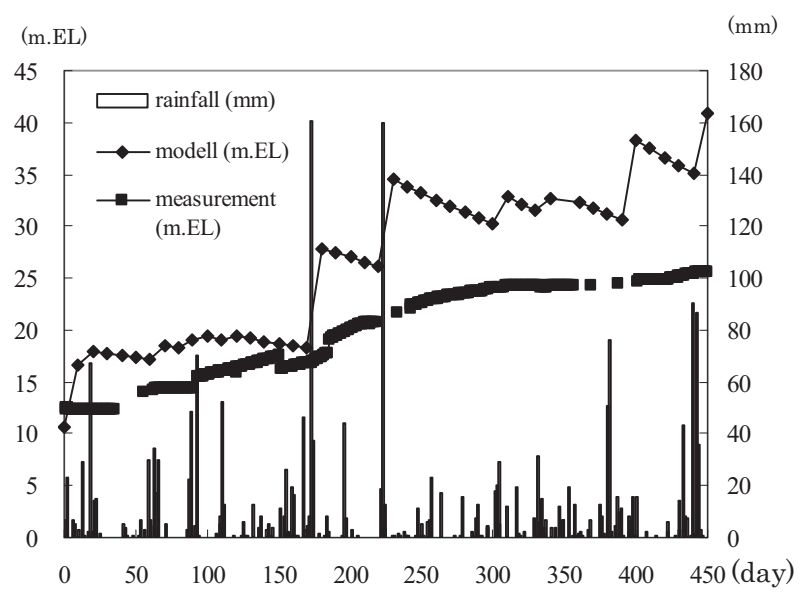

Figure 4: Groundwater level change (after Teranishi et al., 2009)
Now in our present research, calculated velocity distribution within the area is used. Figure 5 is the velocity distribution at 450 days as an example. The distribution is similar of the other time steps. Groundwater moves from west to east. This is probably because the east part has high permeability as shown in Figure 3. The variation of velocity with time at the sample points is shown in Figure 6. It was observed that during the entire period, the highest velocity is $4.93 \mathrm{~m} /$ day at point $\mathrm{A}$ after 240 days and the lowest velocity is $0.72 \mathrm{~m} /$ day at point $\mathrm{B}$ after 170 days.

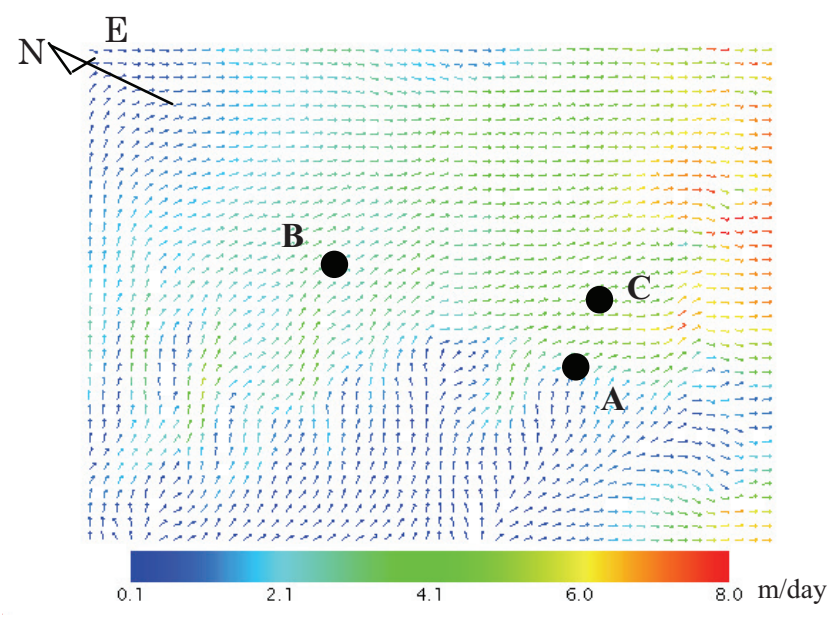

Figure 5: Velocity distribution (450 days)

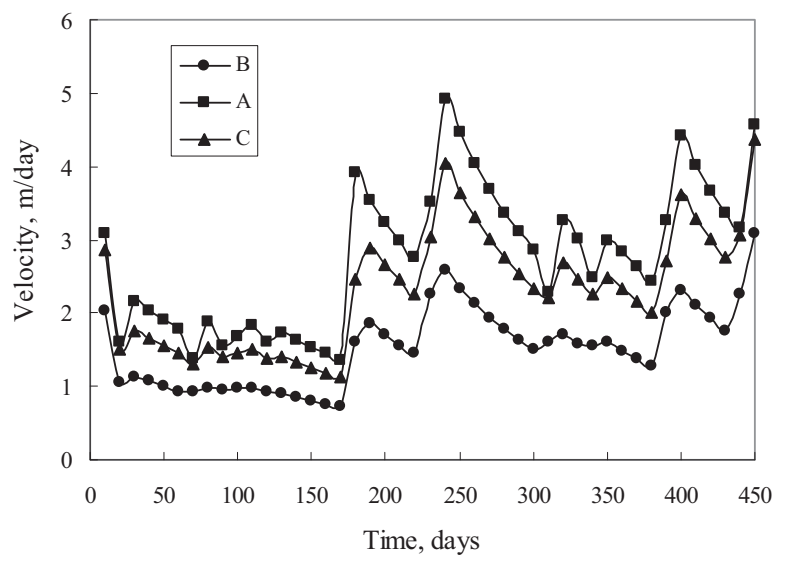

Figure 6: Variation of velocity with time for sample points

\subsection{Ranges of Variation of the Parameters}

As a reference case, it is assumed that recharge water (rain water), with $\mathrm{pH}$ of 5 . The initial condition of groundwater $\mathrm{pH}$ is assumed to be 8 and temperature at the first step is $18^{\circ} \mathrm{C} . \mathrm{pH}$ in groundwater is assumed to change by Eq. (4). The pressure of carbon dioxide is assumed to be $0.003 \mathrm{~atm}$. Boundary condition at downstream boundary is set as $\mathrm{qc}_{\mathrm{k}}$ (third-type), where $c_{k}$ is the concentration and $q$ is the velocity normal to the boundary. The other boundaries were assumed to be no flux condition: $q=0$. To examine the effect of acidity of the aqueous medium on the dissolution of limestone, the $\mathrm{pH}$ is set at 4 . Generally the $\mathrm{pH}$ of acid rain is less than 5.6 and it has been shown that in specific cases 
this $\mathrm{pH}$ can vary from 2.1 to 5.6 (William and Franz, 1981; Babich, 1980; Zhai et al., 2000; Pellett et al., 1981 ). So, assuming the variance of $\mathrm{pH}$ values to be about 1 , we set $\mathrm{pH}$ at 4 for checking the acid rain effect on limestone dissolution. To examine the effect of rain intensity, 10 percent more rainfall is taken. Frank et al. (2007) reported that more rain occurred from increase in surface temperatures due to global warming. United States Environmental Protection Agency, EPA (2000) has also correlated more precipitation with global warming. So, in this study 10 percent more rainfall is taken for checking the rain intensity effect on limestone dissolution. Then, to investigate the effect of temperature change, temperature is taken $1{ }^{\circ} \mathrm{C}$ increase with every 10 days average temperature. Global temperature increment for next century has been estimated to vary from $1.1{ }^{\circ} \mathrm{C}$ to $6.4{ }^{\circ} \mathrm{C}$ (IPCC, 2007; Houghton, 1995; Karl et al., 2000). In this study increase of temperature is assumed to be $1{ }^{\circ} \mathrm{C}$ and temperature in the entire region is changed with every 10 days average temperature to examine the effect.

\section{Results and Discussion}

\subsection{Reference Case}

The distribution of $\mathrm{Ca}^{2+}$ concentration is shown in Figure 7 after 450 days. The highest concentration is $4.13 \mathrm{~mol} / \mathrm{L}$ and occurs close to A whereas it is the minimum at near B. $\mathrm{Ca}^{2+}$ concentration is seen to vary considerably over the region. The figure also shows that the concentration of $\mathrm{Ca}^{2+}$ is higher in the west part than east part. This is due to the velocity is high at the east part than west part of the study region (Figure 5). Figure 8 shows the time variation of the concentration at the sample points. The concentration starts going up after 180 days and continues increasing to 450 days. The increasing concentration indicates the onset of (acid) rain. Again, concentration is highest for point $\mathrm{A}$ $(1.68 \mathrm{~mol} / \mathrm{L})$ and lowest for point $\mathrm{B}$. Due to high concentration of $\mathrm{Ca}^{2+}$ at point $\mathrm{A}$, it will accumulate on the pumping well screen and will be blocked the filter as well. Excess of $\mathrm{Ca}^{2+}$ will deteriorate the quality of groundwater. In this regards, point $\mathrm{B}$ is safer than point $\mathrm{A}$ and $\mathrm{C}$ for groundwater pumping.

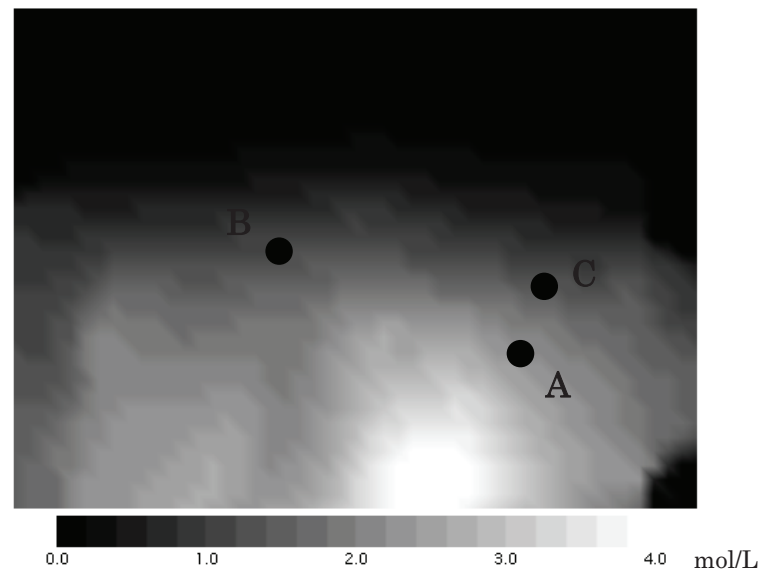

Figure 7: Distribution of $\mathrm{Ca}^{2+}$ (450 days) for reference case

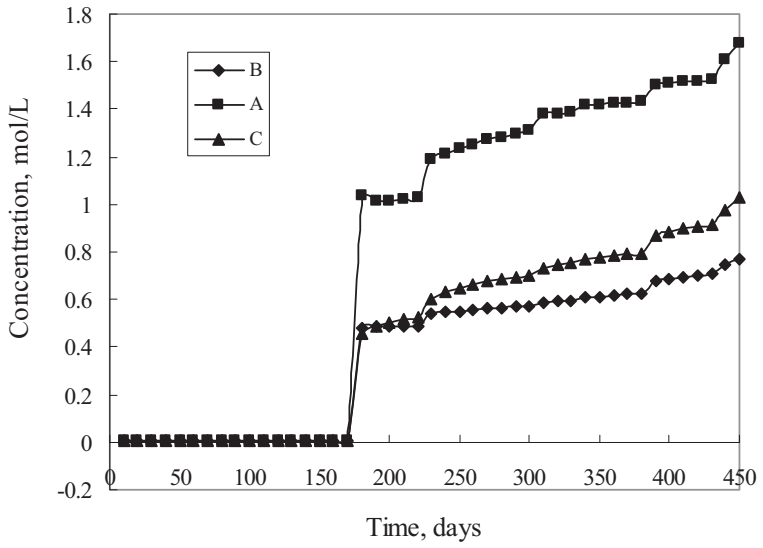

Figure 8: Concentration of $\mathrm{Ca}^{2+}$ with time for sample points for reference case

\subsection{Effect of $\mathrm{pH}$}

Figure 9 shows the spatial distribution of $\mathrm{Ca}^{2+}$ at 450 days after changing the $\mathrm{pH}$ to 4 . Results show that the dissolution increases on decreasing the $\mathrm{pH}$ as $\mathrm{H}^{+}$activity increases. In this case the highest concentration increases up to 205.14 $\mathrm{mol} / \mathrm{L}$ in the west part of study region. This indicates that as the acidification of the rain water progresses, the dissolution of limestone increases. Variation of concentration with time at the sample points for $\mathrm{pH}=4$ is shown in Figure 10 . Of the sample points, concentration is highest for A (76.70 $\mathrm{mol} / \mathrm{L})$ and lowest for $\mathrm{B}(29.80 \mathrm{~mol} / \mathrm{L})$ and for $\mathrm{C}$ it is 40.28 $\mathrm{mol} / \mathrm{L}$.

As $\mathrm{Ca}^{2+}$ increases with acidification, it will accumulate on the pumping well screen and block the filter severely. Excess of $\mathrm{Ca}^{2+}$ will deteriorate the quality of groundwater. While the effect of $\mathrm{pH}$ is reduced by Eq. (4), it can be concluded that the change in $\mathrm{pH}$ has a large effect on the operation of underground dam.

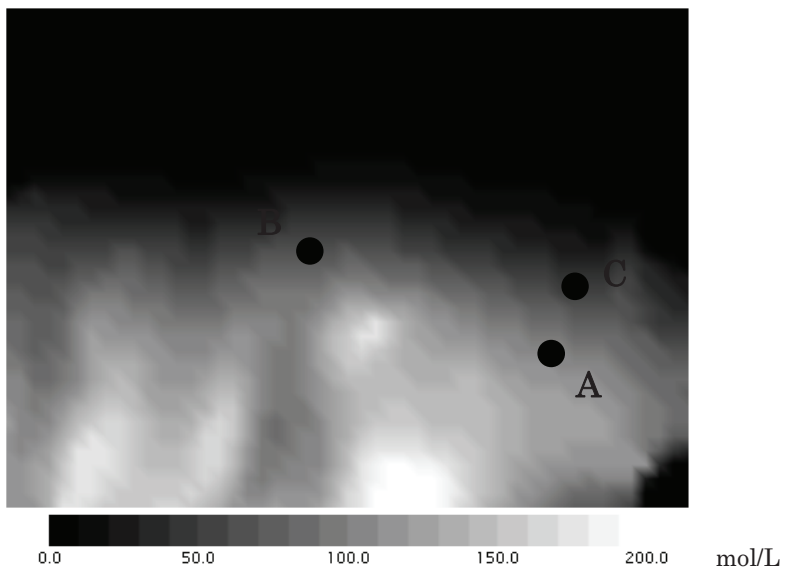

Figure 9: Distribution of $\mathrm{Ca}^{2+}$ ( 450 days) for $\mathrm{pH}=4$ 


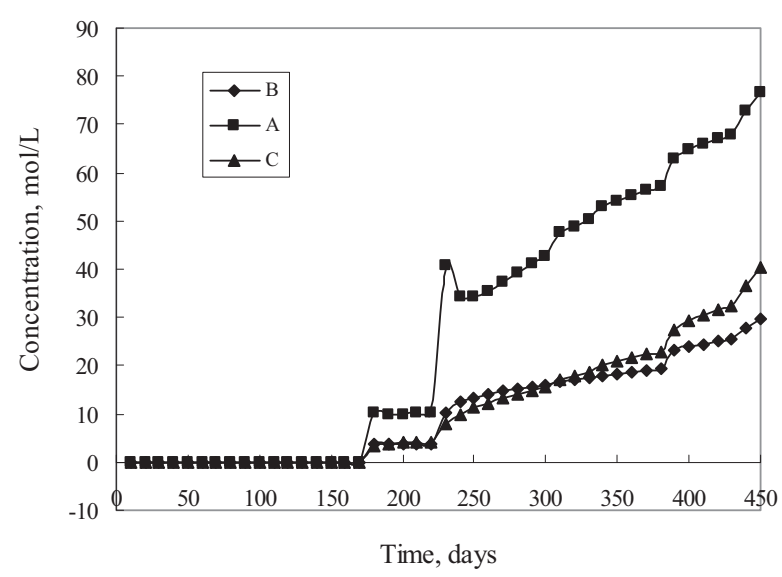

Figure 10: Concentration of $\mathrm{Ca}^{2+}$ with time for sample points for $\mathrm{pH}=4$

\subsection{Effect of Rain Intensity}

The distribution of $\mathrm{Ca}^{2+}$ concentration at 450 days is shown in Figure 11. The results show that the highest concentration of $\mathrm{Ca}^{2+}$ is $5.41 \mathrm{~mol} / \mathrm{L}$ and occurs close to A. The results show that the increase of intensity of rain, which coincides with the increase of velocity, caused the increase in the dissolution of limestone. This is due to transport of the chemicals away from the reaction area near the dam body. Concentrations of $\mathrm{Ca}^{2+}$ with time for the sample points for 10 percent more rainfall are shown in Figure 12. The figure also shows that the concentration is highest for point A $(2.61 \mathrm{~mol} / \mathrm{L})$ and lowest for Point B $(1.27 \mathrm{~mol} / \mathrm{L})$ and for point $\mathrm{C}$ concentration is $1.72 \mathrm{~mol} / \mathrm{L}$.

In this case, Eq. (4) has no effect because rainfall is increased 10 percent both in the maximum rain data in the duration and the rain data at each time step.

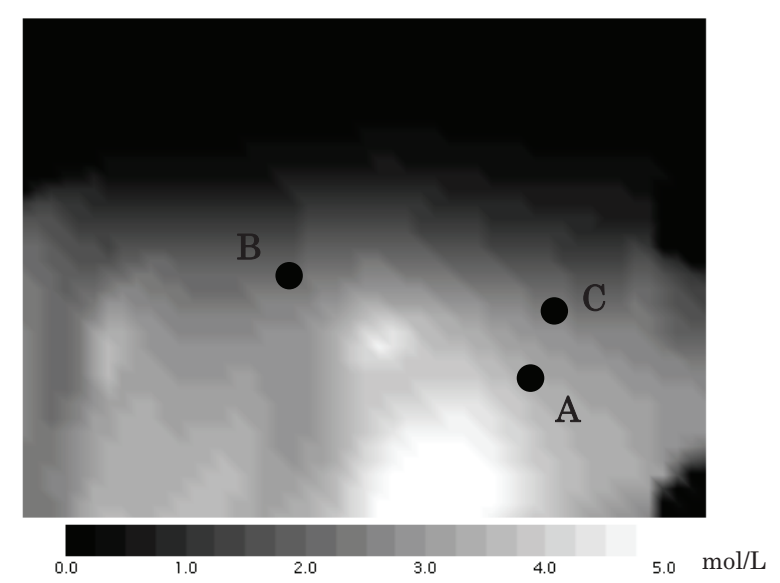

Figure 11: Distribution of $\mathrm{Ca}^{2+}$ (450 days) for 10 percent more rain

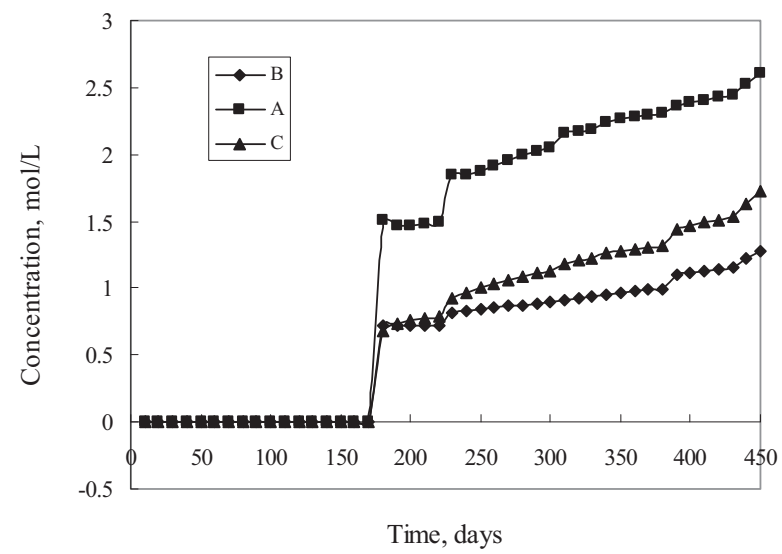

Figure 12: Concentration of $\mathrm{Ca}^{2+}$ with time for sample points for 10 percent more rain

\subsection{Effect of Temperature}

Figure 13 shows the distribution of $\mathrm{Ca}^{2+}$ at 450 days after changing the temperature. In this case results also show that the highest concentration is $4.06 \mathrm{~mol} / \mathrm{L}$ and occurs close to A. Figure 13 shows that the dissolution of limestone decreases from reference with very small variation with increasing the temperature. In this case, dissolution depends on the equilibrium constant of the chemical reactions and those constants are only dependent on temperature. Changing the temperature causes a small change in the equilibrium constants of dissolution reactions and this is the reason behind the small change observed. Due to increase in temperature at $1{ }^{\circ} \mathrm{C}$, the equilibrium constants of $\mathrm{K}_{\mathrm{CO} 2}$ decreases by 3.06 percent and $\mathrm{K}_{\mathrm{CaCO} 3}$ decreases by 0.67 percent. On the contrary, the equilibrium constants of $\mathrm{K}_{\mathrm{H} 2 \mathrm{CO} 3}$ and $\mathrm{K}_{\mathrm{HCO}-}$ increase by 2.40 and 2.45 percent, respectively. Temperature effect on dissolution is very small than other parameters like $\mathrm{pH}$ of rain water and rainfall intensity. The variation in concentration of $\mathrm{Ca}^{2+}$ with time for the sample points at increased temperature is shown in Figure 14. The figure also shows that the concentration is highest for point $\mathrm{A}(1.65 \mathrm{~mol} / \mathrm{L})$ and lowest for Point $\mathrm{B}(0.76 \mathrm{~mol} / \mathrm{L})$ and for point $\mathrm{C}$ concentration is $1.01 \mathrm{~mol} / \mathrm{L}$.

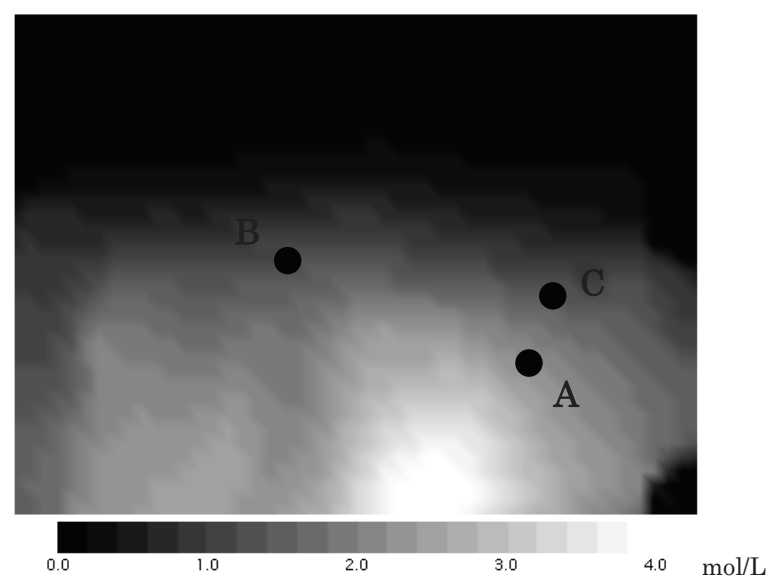

Figure 13: Distribution of $\mathrm{Ca}^{2+}$ (450 days) for 1 degree increase temperature 


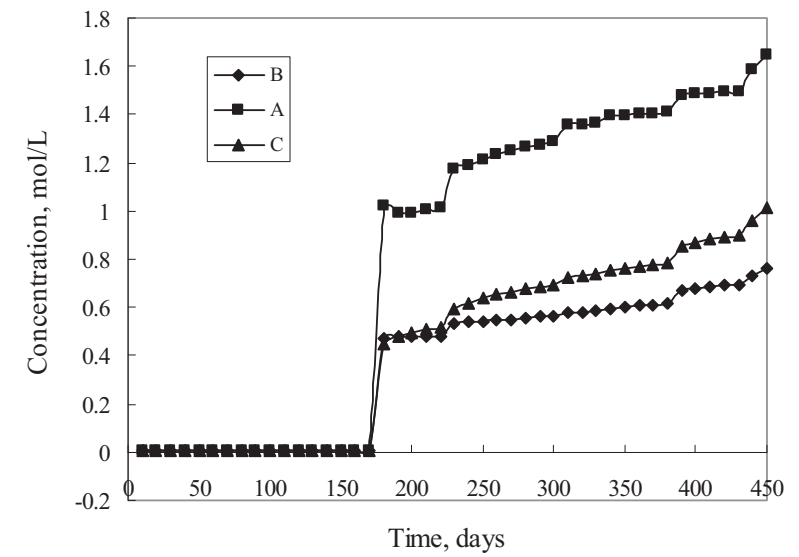

Figure 14: Concentration of $\mathrm{Ca}^{2+}$ with time for sample points for 1 degree increase temperature

\section{Conclusions}

The effect of climatic change on the operation of underground dam was observed by using numerical simulation. From the results several conclusions can be drawn.

1. Dissolution of limestone was increased the most with acidification of rain water. Increasing amount of rainfall increased the dissolution of limestone, while that amount is smaller than the case of decrease of $\mathrm{pH}$. Dissolution decreased with very small quantity from reference case with temperature.

2. Among the sample points $\mathrm{A}, \mathrm{B}$ and $\mathrm{C}$, at point $\mathrm{A}$ the concentrations of $\mathrm{Ca}^{2+}$ were higher than $\mathrm{B}$ and $\mathrm{C}$ for all cases. Pumping well screen will be blocked and sustainable groundwater development will be hampered. Excess $\mathrm{Ca}^{2+}$ will deteriorate the quality of groundwater. It is, therefore, concluded that the pumping at the upstream is favorable for the operation of underground dam and the quality of pumped water.

3. Among all effects of global warming, $\mathrm{pH}$ effect was highest on dissolution of limestone, followed by rainfall effect. It is so concluded that the acidification of water is the major concern for the operation of underground dam.

However, in this research $\mathrm{Ca}^{2+}$ concentrations obtained from numerical simulations but in future it is needed to validate the simulation values of $\mathrm{Ca}^{2+}$ with actual values of $\mathrm{Ca}^{2+}$ of pumped groundwater of that dam area.

\section{Acknowledgement}

The data about the underground dam at Miyakojima were presented by Okinawa branch of Cabinet office, Government of Japan.

\section{References}

[1] Babich, H. (1980): Acid Precipitation- Causes and Consequences. Environment, 22(4), pp. 6-13.

[2] Berner, R.A., and Morse, J.W. (1974): Dissolution Kinetics of Calcium Carbonate in Sea Water IV. Theory of Calcite
Dissolution, Amer. J. Sci., 274, pp.108-134.

[3] Frank J. Wentz, Lucrezia, R., Kyle, H. and Carl, M. (2007): How much more Rain will Global Warming Bring?, Science, 317, pp. 233-235.

[4] Fujino, K., Doyama, K. and Tagawa, S. (2005): Sub-surface Dam in Coastal Area, Res. Rep. Yatsushiro Nat. Coll. Tech. 27, pp. 43-47.

[5] Houghton, J. T., L. Filho, G. M., Callander, B. A., Harris, N., Kattenberg, A., and Maskell, K. (1996): Climate Change 1995: The Science of Climate Change, Intergovernmental Panel on Climate Change, pp. 572, Cambridge University Press, Cambridge, GB.

[6] IPCC (2007): Summary for Policymakers. In: Climate Change 2007: The Physical Science Basis. Contribution of Working Group I to the Fourth Assessment Report of the Intergovernmental Panel on Climate Change [Solomon, S. et al. (eds.)]. Cambridge University Press, Cambridge, United Kingdom and New York, NY, USA.

[7] Karl, T.R., Knight, R.W. and Baker, B. (2000): The Record Breaking Global Temperature of 1997 and 1998: Evidence for an Increase in the Rate of Global Warming?, Geophys. Res. Lett., 27(5), pp. 719-722.

[8] Kaufmann, G., and Dreybrodt, W. (2007): Calcite Dissolution Kinetics in the System $\mathrm{CaCO}_{3}-\mathrm{H}_{2} \mathrm{O}-\mathrm{CO}_{2}$ at High Undersaturation, Geochim. Cosmochim. Acta, 71(6), pp.1398-1410.

[9] Klotz, D., Seiler, K.P., Moser, H. and Neumaier, F. (1980): Dispersivity and Velocity Relationship from Laboratory and Field Experiments, J. of Hydrology, 45, pp. 169-184.

[10] Langmuir, D. (1971): The Geochemistry of some Carbonate Groundwaters in Central Pennsylvania, Geochim. Cosmochim. Acta, 35(10), pp.1023-1045.

[11] Liang, L., Baer, D.R., McCoy, J.M., Amonetie, J.E., and LaFemina, J.P. (1996): Dissolution Kinetics at the Calcite-Water Interface, Geochim. Cosmochim. Acta, 60(23), pp.4883-4887.

[12] Nierode, D.E., and Williams, B.B. (1971): Characteristics of Acid Reaction in Limestone Formations, Soc. Petrol. Eng. J., 251, pp.406-418.

[13] Noiriel, C., Bernard, D., Gouze, Ph. And Thibault, X. (2005): Hydraulic Properties and Microgeometry Evolution Accompanying Limestone Dissolution by Acidic Water, Oil \& Gas Science and Technology - Rev.IFP, 60(1), pp. 177-192.

[14] Pellett, G.L., Bustin, R. and Harris, R.C. (1981): Sequential sampling and variability of acid precipitation in Hampton, Virginia, Water Air and Soil Pollution, 21, pp. 33-49.

[15] Plummer, L.N., Wigley, T.M.L. (1976): The Dissolution of Calcite in $\mathrm{CO}_{2}$-Saturated Solutions at $25^{\circ} \mathrm{C}$ and 1 Atmosphere Total Pressure, Geochim. Cosmochim. Acta, 40(2), pp.191-202.

[16] Plummer, L.N. and Busenberg, E. (1982): The Solubilities of Calcite, Aragonite and Vaterite in $\mathrm{CO}_{2}-\mathrm{H}_{2} \mathrm{O}$ Solutions between 0 and $90^{\circ} \mathrm{C}$, and an Evaluation of the Aqueous Model for the System $\mathrm{CaCO}_{3}-\mathrm{CO}_{2}-\mathrm{H}_{2} \mathrm{O}$, Geochim. Cosmochim. Acta, 46, pp.1011-1040.

[17] Solomon, S., Plattner, G.K., Knutti, R. and Friedlingstein, P. (2009): Irreversible Climate Change due to Carbon dioxide Emissions, Proc. Natl. Acad. Sci. USA, 106(6), pp. 1704-1709.

[18] Sjoberg, E.L., and Rickard, D.T. (1984): Temperature Dependence of Calcite Dissolution Kinetics between 1 and $62^{\circ} \mathrm{C}$ at $\mathrm{pH} 2.7$ to 8.4 in Aqueous Solutions, Geochim. 
Cosmochim. Acta, 48(3), pp.485-493.

[19] Teranishi S., Adham, A.K.M. and Kobayashi, A. (2009): Effect of permeability of underground dam on the performance, The Engineering Institute if Thailand (EIT) - Japanese Society of Civil Engineering (JSCE) joint International Symposium, Bangkok, Thailand.

[20] Thornbush, M.J. and Viles, H.A. (2007): Simulation of the Dissolution of Weathered versus Unweathered Limestone in Carbonic Acid Solutions of Varying Strength, Earth Surf. Process. and Landforms, 32, pp. 841-852.

[21] William, M.L.J. and Franz, H.W. (1981): Acid Rain and Major Seasonal Variation of Hydrogen Ion Loading in a
Tropical Watershed. Acta Cient. Venezolana, 32, pp. 236-238.

[22] Yadav, S.K., and Chakrapani, G.J. (2006): Dissolution Kinetics of Rock-Water Interactions and Its Implications, Current Science, 90(7), pp.932-937.

[23] United States Environmental Protection Agency (EPA). (2000), EPA 430-F-00-011.

[24] Zhai, J., Deng, W., Yan, B., Song, X. and Nie, Y. (2000): Variation of $\mathrm{pH}$ in Atmospheric Precipitation in Cities of Jilin Province. Chinese Geographical Science, 10(2), pp. 182-187.

Discussion open until June 30, 2011 